\title{
Addressing COVID-19 in Afghanistan: What are the efforts and challenges?
}

\author{
Don Eliseo Lucero-Prisno III ${ }^{1 *}$, Attaullah Ahmadi ${ }^{2 *}$, Mohammad Yasir Essar $^{2 *}, \mathrm{Xu}$ \\ Lin $^{3 *}$, Yusuff Adebayo Adebisi ${ }^{4 *}$
}

\author{
${ }^{1}$ Department of Global Health and Development, London School of Hygiene and Tropical Medicine, UK \\ ${ }^{2}$ Kabul University of Medical Sciences, Kabul, Afghanistan \\ ${ }^{3}$ Department of Thoracic Surgery, The First Affiliated Hospital, School of Medicine, Zhejiang University, Hangzhou, Zhejiang, PR China \\ ${ }^{4}$ Faculty of Pharmacy, University of Ibadan, Ibadan, Nigeria \\ *Equal authorship.
}

\section{Shortage of facilities and insufficient PPE deter the fight against COVID-19 and put the health workers at high risk of being in- fected. Limited testing capacity results in underreporting the true number of cases, making people oblivious in following the restrictions and other precautionary mea- sures promoted by the government.}

\begin{abstract}
OVID-19 pandemic is a global public health threat [1]. The first case of COVID-19 was reported in the city of Herat in the western part of Afghanistan on 24 February 2020 [2]. This place borders with Iran where many returnees have seeded new cases in the country [3]. As of 11 June 2020, the virus has spread to all 34 provinces with 22890 confirmed cases and 426 deaths. 3326 patients have recovered so far [4]. Kabul is more highly affected than any other province with 9140 confirmed cases; followed by Herat, Balkh, Nangarhar and Kandahar [5].

When the signs of first cases were reported, the government declared an emergency response to avoid the further spread of the virus. This response was not enough to curb the spread until the time some restrictions in the country were lifted, which followed surges in the cases. At present, the country's indicators are very dire. This article aims at providing a critical commentary on the current efforts against COVID-19 pandemic and the challenges facing its responses in Afghanistan.
\end{abstract}

\section{Efforts}

During the early days of the epidemic in the country, the Ministry of Public Health of Afghanistan had explicitly asserted that people should strictly follow the guidance provided by the ministry otherwise $80 \%$ percent of the whole population will be infected by the virus which may cause many deaths [6]. Thus, the government initiated measures in order to curb the spread of the virus. First, it started to launch the screening program for those entering through the country's porous borders and airports. Those exhibiting the symptoms were carried by ambulances to the isolation centers designated by the Ministry of Public Health, and those without any symptoms were recommended to quarantine at their homes for 14 days [6]. According to the World Health Organization (WHO) [7], as of 3 June 2020, 324464 people have been screened for symptoms. Furthermore, programs on raising awareness in the population in preventing the spread of the virus were conducted. Over 1092889 people have benefited from WASH assistance and hygiene promotion programs [4]. As of now, a total number of 2000 of beds for ICU and isolation centers are operational with a 100bed hospital in Herat and a 300-bed isolation center at Darulaman Palace including two governmental university dormitories [5,7]. 
Lockdown has posed grave implications for the already sluggish economy of Afghanistan. Inadequate assistance from the government to those who lost their income due to the lockdown, forced many people to look for jobs and provisions outside their homes, making COVID-19 containment challenging.

Initially, only one testing laboratory was functional in Kabul. The capacity has been increased to 11 testing laboratories - five in Kabul and one each in Herat, Balkh, Kandahar, Nangarhar, Paktia and Kunduz provinces [5]. Lockdown was first imposed in Herat then subsequently in all major provinces including Kabul. Schools and universities were closed, and restrictions on mass gatherings were imposed. Moreover, restrictions on highways leading to the provincial centers were also included in the plan [6]. Based on that, patients and their immediate family members, returnees, military personnel, and food suppliers were the only ones allowed to use transport on the major highways. The daily routine of governmental and private hospitals was recommended to continue on a daily basis [6]. On 6 June 2020, the government extended the nationwide lockdown for three more months due to the deterioration of the situation. Based on this, provincial authorities could set their own restrictions and regulations according to the severity of the epidemic in their provinces [4].

\section{Challenges}

Afghanistan's fragile health system continues to face many challenges. The protracted conflict in the country has affected the delivery of health care services. Health workers have frequently been targeted and their activities have been discouraged. According to The United Nations Assistance Mission in Afghanistan (UNAMA) [8], a total of 75 incidents in 2019, compared to 65 in 2018, occurred on health care workers and health facilities. These incidents included direct attacks which claimed lives in some cases as well as missing 24000 hours of health care services and 41000 consultations. Of the total 75 incidents, 57 were claimed to have been carried out by anti-government elements including 53 by the Taliban and 17 incidents by other forces. On 12 May 2020, the attack on Dasht-e-Barchi maternity hospital, a governmental MSF (Doctors Without Borders)-assisted hospital which took lives of mothers, babies and health care workers attests to the vulnerability of health care services [9].

Despite devising all aforementioned efforts and strategies, Afghanistan is not fully successful in tussling the virus. The number of new cases in the country is continuously surging with a test positivity rate of 43 percent [4]. The aid to the health sector from the World Bank, foreign countries and foundations has provided some breather but the country still remains ill-equipped to deal appropriately with the progressing predicament. At the present time, not enough personal protective equipment (PPE) are available, thus, threatening the lives of health workers. According to the WHO [7], of the required 425000 PPE, only 15000 are available. This shortage directly accounts to more than five percent of total confirmed cases among health workers in the country.

Insufficient number of health workers and testing capacity, high rate of illiteracy and the adverse economic situation, are other massive challenges in tackling the virus. They continue to contribute to the surges. According to WHO, there are 9.4 skilled health professionals and 1.9 disproportionately distributed physicians per 10000 individuals [2]. As of June 11, 2020, only 52546 individuals out of 37.6 mil-

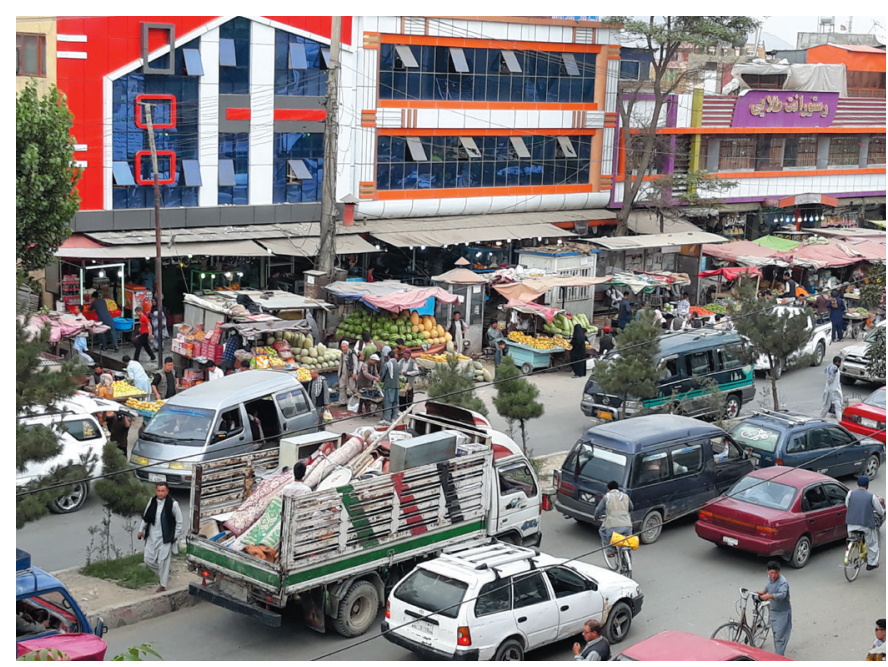

Photo: People busy with their daily routine amid COVID-19 pandemic in the city of Kabul (owned by one of the co-authors, used with permission). lion population have been tested [4]. This implies that the true number of infected cases and deaths are considerably underreported. The Ministry of Public Health of Afghanistan states that they are able to test only 2000 samples out of 10000 to 20000 received daily [10]. Underreporting the real number of cases to the general public has made the population oblivious in seriously following the restrictions as they did during the early days of the crisis.

Since COVID-19 contagion started, Afghanistan's health care system has continuously been facing countless challenges. The situation remains fragile due to many problems the country has been facing for a long period of time. The spread of the virus throughout the country has disproportionately affected the health system in ways where the burden continues to be a heavy load. The government has no other programs to help those who have lost their jobs, except providing needy families with 
bread across the country and waiving water and power bills for select groups in Kabul since the start of the lockdown. These hardly addressed the needs of the people and hence they were forced to leave their homes searching for jobs and other provisions.

In addition, influx of hundreds of thousands of migrants and refugees from Iran, Pakistan, Turkey, and some European Union countries back to Afghanistan has aggravated the situation. Ninety percent of the returnees had left the country due to economic reasons including unemployment [11]. In spite of the unfavorable situation with viral spread, the government, eventually, ratified the plan of lifting restrictions in order to mitigate the worsening economic costs. This policy allowed some businesses, such as money exchange markets and shops, to operate based on a schedule approved by the government as recommended by the Ministry of Public Health. An even-odd license plate policy was also implemented allowing vehicles to operate alternately based on even and odd days thus lessening the number of transports on the road [12].

\section{CONCLUSION}

Afghanistan's current outbreak status clearly shows that the country is heading towards the calamity that experts had warned. Although some level of intensity has been reduced through the help of international donors, still there are many gaps that need to be addressed as soon as possible. A high level of intervention is needed from the wealthy nations and other donors to avoid further catastrophe.

Funding: No funding from any institution or department.

Authorship contributions: AYA, AA, DE L-P conceived the idea. AYA, AA, DEL-P, EMY wrote the draft of the manuscript, collect data and literature. DEL-P and LX assisted with data collection, article interpretation and language edit. All the authors read and approved the final manuscript.

Competing interests: The authors have completed the ICMJE Unified Competing Interest form (available upon request from the corresponding author) and declare no conflicts of interest.

1 Lucero-Prisno DE, Adebisi YA, Lin X. Current efforts and challenges facing responses to 2019-nCoV in Africa. Glob Health Res Policy. 2020;5:21. Medline:32391440 doi:10.1186/s41256-020-00148-1

2 Shah J, Karimzadeh S, Al-Ahdal TMA, Mousavi SH, Zahid SU, Huy NT. COVID-19: the current situation in Afghanistan. Lancet Glob Health. 2020;8:e771-e772. Medline:32247327 doi:10.1016/S2214-109X(20)30124-8

3 Kickbusch I, Leung GM, Bhutta ZA, Matsoso MP, Ihekweazu C, Abbassi K. COVID-19: How a virus is turning the world upside down. BMJ. 2020;369:m1336. Medline:32245802 doi:10.1136/bmj.m1336

4 World Health Organization. Afghanistan Brief: COVID-19, No 52. Available: https://www.humanitarianresponse.info/sites/ www.humanitarianresponse.info/files/documents/files/daily_brief_covid-19_11_june_2020.pdf Accessed: 11 June 2020

5 U.S Embassy in Afghanistan. Available: https://af.usembassy.gov/covid-19- information/. Accessed: 11 June 2020.

6 Ministry of Public Health. Measures taken by the Ministry of Public Health for preventing and controlling the spread of the coronavirus in Afghanistan. Available: https://moph.gov.af/. Accessed: 4 June 2020.

7 World Health Organization. Afghanistan Brief: COVID-19, No 50. Available: https://www.humanitarianresponse.info/ sites/www.humanitarianresponse.info/files/documents/files/operational_sitrep_covid-19_04_june_2020.pdf. Accessed: 4 June 2020.

8 UNAMA. Afghanistan Annual Report on Protection of Civilian in Armed Conflict: 2019. Available: https://unama.unmissions.org/sites/default/files/afghanistan_protection_of_civilians_annual_report_2019_-_22_february.pdf. Accessed: 12 June 2020 .

9 BBC. Afghan attack: Maternity ward death toll climbs to 24. Available: https://www.bbc.com/news/world-asia-52642503. Accessed: 12 June 2020.

10 Faiez R. Lack of virus tests pushes Afghanistan toward crisis. Available: https://thediplomat.com/2020/06/lack-of-virustests-pushes-afghanistan-toward-crisis/. Accessed: 4 June 2020.

11 Mixed Migration Center. Understanding the impact of COVID-19 on returnees. Available: http://www.mixedmigration. org/wp-content/uploads/2020/05/102_covid_snapshot_asia.pdf. Accessed: 12 June 2020.

12 Office of the president of Afghanistan. Gradual relaxation of the lockdown. Available: https://president.gov.af/da/?p=25128 Accessed: 4 June 2020 